J. Pijar MIPA, Vol. VI No.1, Maret : 1 - 4

ISSN 1907-1744

\title{
PENGEMBANGAN MODUL PEMBELAJARAN LARUTAN ASAM BASA BERBASIS PENDEKATAN MMS (MAKROSKOPIK MIKROSKOPIK SIMBOLIK) DAN IMPLEMENTASINYA DALAM PEMBELAJARAN
}

\author{
Rina Aprianti' ${ }^{1)}$, Wildan' ${ }^{2}$, Muntari $^{2)}$ \\ ${ }^{1)}$ Dosen FKIP Universitas Muhammadiyah Mataram \\ ${ }^{2)}$ Dosen FKIP Universitas Mataram
}

\begin{abstract}
Abstrak : Penelitian bertujuan untuk mengembangkan modul dan perangkat pembelajaran Larutan Asam Basa berbasis pendekatan MMS (Makroskopik Mikroskopik Simbolik) dan menguji efektivitasnya dalam pembelajaran. Penelitian dilaksanakan dalam dua tahap, yaitu pengembangan bahan ajar dalam bentuk modul dan implementasi modul dalam kegiatan pembelajaran di dalam kelas. Pengembangan modul dan perangkat pembelajaran menggunakan model Dick and Carey sebagaimana digunakan oleh Tucker [1]. Implementasi hasil pengembangan dilakukan melalui penelitian eksperimen dengan rancangan post-test only non equivalent kontrol group design dengan mengambil dua kelas homogen secara intact group dari lima kelas yang tersedia. Hasil pengembangan terdiri dari bahan ajar dalam bentuk modul, perangkat pembelajaran meliputi silabus, RPP, dan instrumen penilaian. Hasil validasi ahli terhadap bahan ajar dalam bentuk modul, silabus, RPP, dan instrumen penilaian dikategorikan sangat baik dan layak digunakan. Hasil penilaian siswa secara perorangan terhadap modul dikategorikan sangat baik, dan secara kelompok dikategorikan baik. Implementasi pembelajaran modul Asam-basa berdasarkan pendekatan MMS telah menghasilkan prestasi kognitif siswa secara signifikan lebih baik dibandingkan dengan siswa di kelas dengan pendekatan konvensional.
\end{abstract}

Kata kunci : Pendekatan, makroskopik, mikroskopik, simbolik, hasil belajar

Abstract : The research aims were to develop learning modules and learning packages Acid-Base Solvent based on to MMS (Macroscopic, Microscopic, Symbolic) approach and test its effectiveness in learning. Research was conducted in two phases, that is the development of teaching materials in the form of modules and the implementation of modules in the learning activities in classrooms. Developing learning modules and devices using the Dick and Carey model as used by Tucker [1]. The implementation of the development carried out through the design of experimental studies with post-test only non equivalent control group design by taking two classes intact homogenous group of five classes available. The results the the development consist of teaching materials in the form of modules, learning tools including syllabi, lesson plans, and assessment instruments. The results of the expert validation of teaching materials in the form of modules, syllabi, lesson plans, and assessment instruments categorized as very good and valid for use. As individuals towards student assessment results of modules categorized as very good, and a group of well categorized. The implementation Acid-base learning module based on the MMS approach has resulted in students' cognitive achievement was significantly better than students in the class with the conventional approach.

Key words : Approach, macroscopic, microscopic, symbolic, cognitive achievement

\section{PENDAHULUAN}

Sebagian besar konsep dalam ilmu kimia memiliki tingkat generalisasi dan keabstrakan yang tinggi. Sebagai contoh pada pembentukan endapan $\mathrm{BaSO}_{4}$ dari $\mathrm{BaCl}_{2}$ dan $\mathrm{H}_{2} \mathrm{SO}_{4}$ yang hanya dilambangkan dengan persamaan reaksi:

$$
\mathrm{BaCl}_{2(\mathrm{aq})}+\mathrm{H}_{2} \mathrm{SO}_{4(\mathrm{aq})} \rightarrow \mathrm{BaSO}_{4(\mathrm{~s})}+2 \mathrm{HCl}_{(\mathrm{aq})}
$$

Konsep-konsep yang digeneralisasi dan disederhanakan seperti ini menyebabkan konsep-konsep dalam ilmu kimia menjadi ilmu yang abstrak, sulit dan menjadi salah satu mata pelajaran yang sulit bagi sebagian siswa [2]. Hal lainnnya yang menjadi karakteristik ilmu kimia adalah pada banyaknya materi yang harus dipelajari sesuai dengan tuntutan kurikulum kimia SMA. Akibatnya, untuk mengejar ketuntasan materi sebagian guru cenderung menggunakan metode ceramah dalam mengajar di dalam kelas.

Pembelajaran dengan metode ceramah, membutuhkan kemampuan berpikir tingkat tinggi (kemampuan berpikir abstrak yang baik). Hal ini disebabkan karena dalam pembelajaran dengan metode ceramah, terjadi transfer informasi dari guru kepada siswa yang banyak melibatkan komunikasi verbal. Dalam prosesnya, penyajian informasi dengan metode ceramah dilakukan melalui tahapan, pertama guru mengubah informasi yang dimilikinya menjadi ide-ide dan gagasangagasan yang dikomunikasikan secara verbal atau dengan memberikan lambang-lambang tertentu; kedua, ide dan lambang ini diterima siswa kemudian siswa mengubahnya kembali menjadi ide-ide yang dimiliki siswa [3].

Fakta di lapangan menunjukkan bahwa sebagian siswa SMA bahkan mahasiswa sekalipun masih berada pada kemampuan berpikir transisi antara konkrit dan abstrak [4]. Sehingga jika pembelajaran didominasi dengan metode ceramah maka besar kemungkinan untuk terjadinya miskonsepsi yaitu perbedaan antara guru dan siswa dalam memahami suatu konsep tertentu [5]. Dengan demikian diperlukan bantuan media pembelajaran untuk membantu siswa dalam menginterpretasi informasi yang diterima dari guru. Secara khusus, penggunaan media pembelajaran berfungsi untuk menggambarkan segitiga konsep dalam ilmu kimia (makro, mikro, simbolik) [6].

Media pembelajaran merupakan media pengantar pesan yang ingin disampaikan oleh guru kepada siswa. Media pembelajaran dapat digolongkan menjadi tiga macam, yaitu media audio, video, dan audio visual [7]. 
Modul merupakan salah satu bentuk media visual berupa bahan ajar cetak yang memiliki karakteristik yang khas. Modul sebagai media pembelajaran dapat dieksplorasi untuk membantu siswa memahami konsep-konsep dalam ilmu kimia baik pada aspek makro, mikro, dan simbolik [8].

Berdasarkan analisis materi asam basa yang terdapat di kelas XI, diketahui bahwa 57\% konsep merupakan konsep abstrak, 28\% berupa konsep-konsep yang dapat dipraktikumkan/didemonstrasikan, dan 15\% materi dapat diajarkan melalui pengajaran langsung $[9$, 10]. Dengan demikian, diharapkan dengan penyusunan modul pembelajaran yang mengintegrasikan ketiga level pemahaman dalam ilmu kimia ini dapat menunjang pembelajaran kimia di SMA.

\section{METODE PENELITIAN}

Penelitian ini terdiri dari dua tahap, yaitu penelitian pengembangan dan penelitian eksperimen. Penelitian pengembangan menggunakan desain model pengembangan Dick and Carey sebagaimana yang digunakan oleh Tucker [1], terdiri dari 10 langkah. Kesepuluh tahap dalam pengembangan perangkat oleh Dick and Carey dapat digambarkan sebagai berikut:

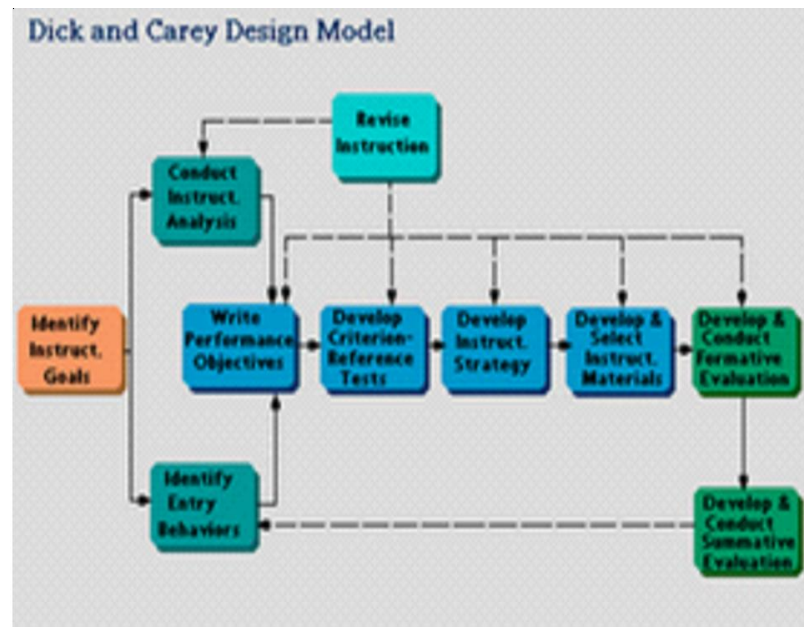

Sumber : Tucker, 2002

Hasil pengembangan berupa modul dan perangkat pembelajaran lainnya dinilai kelayakannya oleh ahli bidang pembelajaran, ahli bidang kimia, dan tanggapan siswa terhadap modul yang dihasilkan [11].

Penelitian eksperimen menggunakan rancangan kuasi eksperimen dengan postes only non equivalent kontrol group design [12]. Desain penelitian digambarkan sebagai berikut:

\begin{tabular}{ccc}
\hline Kelompok Kelas & Perlakuan & Postes \\
\hline Kontrol & - & $\mathrm{v}$ \\
Uji coba & $\mathrm{v}$ & $\mathrm{v}$ \\
\hline
\end{tabular}

Penelitian ini dilaksanakan dengan mengambil dua kelas secara intact group dengan pertimbangan kemampuan awal siswa yang setara. Data kemampuan awal berupa nilai akhir semester I kelas XI. Berdasarkan uji pendahuluan, diperoleh dua kelas dari lima kelas memiliki kemampuan awal kimia yang sama, yaitu kelas XI IPA 2 (eksperimen) dan kelas XI IPA 3 (kontrol).

Instrumen yang dikembangkan berupa tes hasil belajar kognitif siswa, lembar observasi, dan angket siswa [12]. Teknik analisis data dilakukan dengan analisis deskriptif (kualitatif dan kuantitatif) [13]. Analisis kualitatif dilakukan untuk menggambarkan proses pembelajaran yang berlangsung, sedangkan analisis kuantitatif dilakukan untuk menjawab hipotesis penelitian yang berbunyi: "Nilai rata-rata kimia siswa yang belajar dengan modul pembelajaran berbasis pendekatan MMS lebih tinggi dibandingkan dengan nilai rata-rata kimia siswa yang belajar dengan pendekatan konvensional" [14].

\section{HASIL DAN PEMBAHASAN}

Produk pengembangan yang dihasilkan dalam penelitian pengembangan adalah (1) bahan ajar dalam bentuk modul pembelajaran berbasis pendekatan MMS, (2) perangkat pembelajaran berupa silabus dan RPP, serta (3) instrumen evaluasi yang disusun dalam bentuk tes uraian obyektif. Kualitas hasil pengembangan diperoleh dari hasil validasi (pakar, siswa pada uji perorangan, dan siswa pada kelompok kecil). Tim ahli terdiri dari dua orang akademisi, dan dua orang praktisi (guru kimia). Aspek-aspek penilaian tim ahli terhadap modul dan perangkat pembelajaran yang disusun adalah ketatabahasaan, kesesuaian materi dengan indikator pembelajaran, validitas isi, dan kebenaran konsep. Tanggapan ahli terhadap modul, RPP, dan instrumen penilaian termasuk kategori sangat baik dan layak digunakan. Nilai rata-rata yang diberikan tim ahli terhadap modul, RPP, dan instrumen penilaian secara berturut-turut adalah 3,$77 ; 3,71$ dan 3,80 dari rata-rata total 4,00 . Penilaian siswa terhadap modul pembelajaran yang dilakukan pada uji perorangan termasuk kategori sangat baik dengan nilai rata-rata 3,42. Sedangkan penilaian siswa pada uji kelompok kecil dengan nilai rata-rata 3,27 termasuk kategori baik. Aspek penilaian siswa baik yang dilakukan pada uji perorangan maupun uji kelompok kecil adalah untuk melihat kemenarikan dan keterbacaan naskah modul.

Hasil penelitian eksperimen diperoleh melalui lembar observasi dan angket untuk mengetahui kualitas proses pembelajaran, sedangkan data hasil belajar diperoleh melalui postes yang dilakukan setelah pembelajaran selesai dilaksanakan. Hasil observasi yang dilakukan observer menunjukkan bahwa kualitas proses pembelajaran yang dilakukan menggunakan modul berbasis pendekatan MMS masih perlu ditingkatkan. Kesimpulan ini diperoleh dari banyaknya masukan baik yang diberikan oleh observer maupun siswa sebagai subyek penelitian. Berikut adalah masukan-masukan observer terhadap aktivitas guru selama penelitian dilaksanakan (1) peneliti terkesan terburu-buru dalam menyampaikan materi, (2) distribusi waktu pada masingmasing kegiatan perlu disesuaikan, (3) guru tidak perlu menyampaikan kesimpulan di akhir pembelajaran, karena sudah ada di dalam modul, (4) guru perlu membangun interaksi dengan siswa melalui pertanyaan-pertanyaan yang memancing perhatian dan rasa ingin tahu siswa, (5) perlu peningkatan aktivitas guru dengan cara ketika 
menjelaskan disertai dengan tanya jawab, dan (6) guru selalu berpindah-pindah ketika memberikan penjelasan. Catatan observer terhadap aktivitas siswa selama proses pembelajaran, diantaranya (1) siswa kurang aktif dalam kegiatan pembelajaran karena kegiatan didominasi oleh guru, (2) ada siswa yang mengobrol yang luput dari perhatian guru, (3) pada topik-topik tertentu, kelas berjalan baik dan kondusif, (4) siswa terlihat tidak nyaman dengan aktivitas guru yang selalu berpindah-pindah tempat ketika memberikan penjelasan, dan (5) siswa senang ketika guru memberikan kesempatan kepada siswa untuk menyelesaikan soal latihan di depan kelas.

Angket siswa menunjukkan informasi mengenai profil tanggapan siswa secara umum mengenai proses pembelajaran yang berlangsung di dalam kelas. Dari 40 siswa yang diberikan angket, diperoleh profil meliputi aspek sikap siswa bahwa $72,5 \%$ memperhatikan dengan baik penjelasan guru, $57,5 \%$ siswa lebih termotivasi belajar, $42,5 \%$ siswa memanfaatkan ilustrasi yang terdapat di dalam modul, $37,5 \%$ termotivasi untuk lebih bertanggung jawab dan respon siswa terhadap proses pembelajaran, $20 \%$ siswa memahami dengan baik materi yang diajarkan dengan menggunakan modul berbasis MMS, 17,5\% kreativitas siswa meningkat, dan 15\% siswa menjadi lebih aktif bertanya mengenai konsep-konsep yang belum dipahaminya.

Untuk menjawab hipotesis yang diajukan, perlu dilakukan analisis perbedaan dua rerata yang diperoleh menggunakan teknik uji-t dengan terlebih dahulu melakukan uji persyaratan yang meliputi (1) uji normalitas menggunakan teknik Kolmogorov-Smirnov. Hasil uji menunjukkan bahwa data dalam populasi terdistribusi normal dengan harga $p>0,05$. Harga $Z$ untuk kelas kontol dan kelas eksperimen secara berturut-turut adalah 1,235 dan 0,922. (2) uji homogenitas varians data menggunakan teknik Levene's test. Hasil uji menunjukkan bahwa kedua kelompok data memiliki varians yang homogen, yaitu $p>$ $0,05$ (dimana $p=0.298)$. Semua analisis dilakukan dengan menggunakan program SPSS for windows versi 16 pada interval kepercayaan 95\%. Selanjutnya, analisis dilanjutkan terhadap nilai postes yang digunakan untuk mengetahui efektivitas penerapan modul dalam pembelajaran. Hasil analisis menunjukkan bahwa nilai rata-rata kimia siswa yang belajar dengan modul berbasis pendekatan MMS dan yang belajar secara konvensional $(66,3>55,8)$ berbeda secara signifikan,yaitu $\mathrm{p}<0,05$ (p $=0,005)$. Hal ini berarti bahwa pembelajaran yang menerapkan modul berbasis pendekatan MMS efektif untuk diterapkan dalam pembelajaran kimia. Namun demikian, walaupun hasil analisis menunjukkan perbedaan yang signifikan antara pembelajaran yang menerapkan modul berbasis pendekatan MMS dengan pembelajaran konvensional tetapi jika ditinjau dari kualitas skor ratarata yang diperoleh maka hasil yang diperoleh tersebut masuh perlu ditingkatkan. Terlebih dengan ketercapaian ketuntasan klasikal yang hanya $52,5 \%$ untuk kelas eksperimen dan 26,2\% untuk kelas kontrol $(\mathrm{KKM}=71)$.

Analisis terhadap faktor-faktor yang menyebabkan masih rendahnya nilai rata-rata siswa pada kelas eksperimen disebabkan oleh tiga faktor, yaitu pelaksanaan penelitian, pengelolaan kelas, dan pemilihan strategi pembelajaran. Faktor pertama, pelaksanaan penelitian. Peneliti tidak memiliki perencanaan kegiatan yang baik dalam melaksanakan pembelajaran bermodul, yaitu (1) seharusnya modul dibagikan kepada siswa paling lambat seminggu sebelum pembelajaran dilaksanakan, (2) pada setiap akhir unit dilakukan tes formatif dan tugastugas latihan yang terstruktur, (3) hasil tes dan tugas-tugas yang dikerjakan siswa, dikoreksi dan dikembalikan dengan feedback yang terstruktur paling lambat sebelum pembelajaran unit materi berikutnya, dan (4) memberi kesempatan kepada siswa yang belum berhasil menguasai materi ajar berdasarkan hasil analisis tes formatif dipertimbangkan sebagai hasil diagnosis untuk menyelenggarakan program pembelajaran remedial pada siswa di luar jam pelajaran [15]. Faktor kedua, pengelolaan kelas. Berdasarkan hasil evaluasi pelaksanaan pembelajaran, baik evaluasi dari observer maupun siswa sebagai subyek penelitian menunjukkan bahwa lemahnya pengelolaan kelas yang dijalankan oleh peneliti selama kegiatan berlangsung [16]. Faktor ketiga, pemilihan strategi pembelajaran. Strategi pembelajaran memegang peranan penting dalam mengaktifkan siswa dan keberhasilan guru dalam mengelola kelas secara umum. Menurut Santyasa [17], pelaksanaan pembelajaran menggunakan modul seharusnya dilaksanakan dalam model pembelajaran kooperatif konstruktivistik. Dengan demikian ruang diskusi dan interaksi antara siswa dengan siswa, siswa dengan guru, dan siswa dengan sumber belajar menjadi lebih optimal. Pembelajaran dengan pendekatakan konstruktivistik ditekankan untuk membangun pengetahuan siswa dengan upayanya sendiri, sehingga pengetahuan itu akan menjadi miliknya [18]. Berbagai model pembelajaran berbasis pendekatan konstruktivistik di antaranya adalah pembelajaran berbasis inkuiri melalui strategi kooperatif [19]. Model pembelajaran ini tepat diterapkan dengan menggunakan modul sebagai bahan ajar yang dapat digunakan siswa sebagai sumber informasi tentang masalah yang dihadapi secara kelompok.

\section{KESIMPULAN DAN SARAN}

Bertolak dari rumusan masalah yang ingin diketahui jawabannya melalui penelitian ini, maka dari temuan dan pembahasan yang telah dipaparkan dapat diberikan kesimpulan sebagai berikut, (1) telah dihasilkan perangkat pembelajaran pada materi pokok larutan asam basa berbasis pendekatan MMS yang terdiri dari modul pembelajaran, silabus, RPP, dan instrumen penilaian (tes), (2) berdasarkan hasil validasi ahli, modul dan perangkat pembelajaran yang dihasilkan berupa silabus, RPP, dan instrumen penilaian termasuk kategori sangat baik dan layak digunakan, (3) hasil validasi oleh siswa pada uji perorangan terhadap modul pembelajaran dikategorikan sangat baik, sedangkan pada uji kelompok kecil dikategorikan baik, dan (4) perangkat pembelajaran yang terdiri dari modul pembelajaran, silabus, RPP, dan instrumen penilaian efektif diterapkan dalam pembelajaran kimia, khususnya pada materi pokok larutan asam basa.

Saran-saran yang dapat diajukan peneliti untuk menjadi masukan bagi pembaca yang ingin menindaklanjuti hasil penelitian ini adalah (1) modul dan perangkat pembelajaran yang dihasilkan dapat 
dimanfaatkan oleh sekolah-sekolah lain yang memiliki karakteristik sama dengan tempat penelitian, (2) untuk dapat dimanfaatkan lebih lanjut, produk penelitian pengembangan ini perlu disosialisasikan terhadap guruguru lain melalui MGMP, (3) untuk mendukung keterlaksanaan Kurikulum Berbasis Kompetensi (KBK) perlu diprogramkan kegiatan untuk meningkatkan kemampuan guru dalam mengembangkan bahan ajar yang kontekstual dan mudah dipelajari oleh siswa, dan (4) untuk mengetahui lebih jauh mengenai pengaruh penerapan modul dalam pembelajaran, diperlukan penelitian lanjutan dengan memperhatikan kaidah-kaidah pembelajaran bermodul.

\section{DAFTAR PUSTAKA}

[1] Tucker, D. 2002. The Application of the Dick and Carey Systems Approach Model to a Macromedia ${ }^{\circledR}$ Flash Tutorial. Master's Project. Instructional Design and Technology. Emporia State University. Diunduh melalui: http:// www.student.seas.gwu.edu/ tlooms/ISD/GIFS/ dc design.gif pada hari Sabtu 12 Desember 2009.

[2] Kean, E. \& Middlecamp, C. 1994. How to Survive and Even Excel in General Chemistry. New York: McGraw-Hill.

[3] Sihaloho, M. 2001. Analisis Pemahaman Konsep Larutan Elektrolit melalui Penggambaran Mikroskopik Siswa dan Guru di SMUN Kotamadya Gorontalo. Tesis tidak dipublikasikan. Program Pascasarjana Program Studi Pendidikan Kimia Universitas Negeri Malang.

[4] Ardhana. 1983. Kesanggupan Berpikir Formal ala Piaget dan Kemajuan Belajar di Sekolah. Disertasi. Tidak dipublikasikan. Fakultas Pasca Sarjana Institut Keguruan dan Ilmu Pendidikan. Malang.

[5] Nakhleh, B. M. 1992. Why Some Student Dont Learn Chemistry. Chemical Misconceptions. Journal of Chemical Education. 69 (3) : 191-196.

[6] Anugerah, S. H. 2007. Analisis Kemampuan Makroskopik, Mikroskopik dan Simbolik dalam Materi Reaksi Uraian Berganda pada Siswa Kelas XII IPA-1 SMA Negeri Turen. Skripsi tidak dipublikasikan. Fakultas Matematika dan Ilmu Pengetahuan Alam Jurusan Kimia Program Studi Pendidikan Kimia Universitas Negeri Malang. Malang.

[7] Heinich, R., Molenda, M., Russell, J. D., \& Smaldino, S.E. 2002. Instructional media an technology for learning, 7th edition. New Jersey: Prentice Hall, Inc.

[8] Russel, J. W., Kozma, R. B., Jones, T., Wyskoff, Marx dan Davis, J. 1997. Use of Simultaneous Syncronized Macroscopic, Microscopic and Symbolic Representations to Enchance the Teaching and Learning of Chemical Concepts. Journal of Chemical Education. 74 (3): 330-334.
[9] Effendy. 2007. A-Level Chemistry for Senior High School Students. Volume IB. Bayumedia Publishing. Malang.

[10] Purba, M. 2007. Kimia. Untuk SMA Kelas XI. Semester 2. Erlangga. Jakarta.

[11] Tim Puslitjaknov. 2008. Metode Penelitian Pengembangan. Pusat Penelitian Kebijakan dan Inovasi Pendidikan. Badan Penelitian dan Pengembangan Departemen Pendidikan Nasional.

[12] Arikunto, S. 2003. Dasar-Dasar Evaluasi Pendidikan (Edisi Revisi). Bumi Aksara. Jakarta.

[13] Sugiyono. 2009. Metode Penelitian Pendidikan. Pendekatan Kuantitatif, Kualitatif dan $R \& D$. Alfabeta. Bandung.

[14] Sudjana. 2002. Metoda Statistika. Edisi Ke 6. Tarsito. Bandung.

[15] Aswan. 1995. Strategi Belajar Mengajar. PT. Rineka Cipta. Jakarta.

[16] Suprayekti. 2003. Interaksi Belajar Mengajar. Depdiknas. Jakarta.

[17] Santyasa, W. 2009. Metode Penelitian Pengembangan dan Teori Pengembangan Modul. Makalah. Disajikan dalam pelatihan bagi para guru TK, SD, SMP, SMA dan SMK tanggal 12-14 Januari 2009 di Kecamatan Nusa Penida Kabupaten Klungkung. Diunduh melalui: http:// www.freewebs.com/santyasa/pdf2/ METODE_PENELITIAN.pdf pada tanggal 15 Maret 2011.

[18] Muntari. 2018. Pendekatan Konstruktivisme dalam Pembelajaran Kimia. JURNAL ILMU PENDIDIKAN, Vol. 62 Tahun XIX

[19] Jufri, A. W. 2007. Pengaruh Implementasi Pembelajaran Berbasis Inkuiri Melalui Strategi Kooperatif Terhadap Keterampilan Berpikir Kritis, Sikap dan Hasil Belajar Kognitif SMA. Disertasi tidak dipublikasikan. Program Pascasarjana Universitas Negeri Malang. Malang. 